\title{
Performance of Potential Pozzolanic Cement in Chloride media
}

\author{
Marangu J.M ${ }^{1}$, Muthengia J.W ${ }^{2}$ and wa- Thiong'o J.K ${ }^{1}$ \\ ${ }^{1}$ Chemistry Department, Kenyatta University -Nairobi, Kenya \\ ${ }^{2}$ Embu University College (A Constituent College of the University of Nairobi) - Kenya
}

\begin{abstract}
The paper presents finding of the pozzolanic activity of calcined clays from selected regions of Embu County - Kenya. The results are also presented for the compressive strength development and Chloride ingress resistance of the blend of the calcined clays with Ordinary Portland Cement (OPC), vis a vis commercial OPC and Portland Pozzolana cement (PPC). The objective of the study was to investigate the viability of using locally available materials to make affordable cementitious materials. Sampled clays were activated at different temperatures and time and blended with OPC at different replacement levels. The blends were subjected to accelerated chloride ingress. The blended cement and commercial PPC showed lower chloride ingress, in terms of apparent diffusion coefficients, compared to OPC with the blended cement exhibiting least chloride ingress
\end{abstract}

Keywords: Pozzolana, Calcined Clays, Blended Cement

\section{Introduction}

There is an inherent desire by most people to own decent and affordable houses. On average, the cost of building materials for a housing structure comprises about 50 percent of the total cost of the building (Jones and Dhir, 2000). For lower income shelters this percentage could rise to as much as 80 percent depending on the country where the construction occurs (Laban and Benedetti, 2002; Jones and Dhir, 2000). The high cost is normally attributed to the high prices of cement. A majority of the citizens in developing countries, especially where the Government do not have an established housing and shelter system, cannot afford the cement, which is a major building binder for housing and construction in general (Muthengia, 2008). This has lead to the mushrooming of slums such as Kibera in Nairobi-Kenya. There is an increasing demand for decent housing as the shanty houses poses various health challenges (Ghebreyesus et al., 2000).

The cost of construction materials is increasing day by day because of high demand, scarcity of raw materials and high price of energy. Portland cement is the most common type of cement used in construction. It is an expensive binder due to the high cost of production associated with the high energy requirements of its manufacturing process (Neville, 1995). From the standpoint of energy saving and environmental conservation, the use of alternative constituents in construction materials is now a global concern.

Other relatively low cost materials with cementitious properties are natural pozzolana such as volcanic tuff, clay and waste products from industrial plants such as slag, fly ash and silica fume. They can be used as a partial replacement for Portland cement to make blended cements. In addition, to reduce the cost of binder, there are potential technological benefits from the use of pozzolanic materials as those blended with Portland cement in concrete applications. These include decreased permeability of aggressive ions and increased ultimate strength and durability of concrete. These benefits have lead to an increased demand for pozzolanic materials for use in making pozzolanic cements. The objective of this study was to investigate the potential use of calcined clays from Runyenjes in Kenya as pozzolana.

\section{Materials and methods}

Sampling

In this study raw clays were sampled from three different places within Ugweri region (longitude $37^{0}$ $34^{\prime} 19.47^{\prime}$ ' E, latitude $0^{0} 25^{\prime} 20.44^{\prime \prime}$ S) in Eastern province in Kenya. In each place, three clay samples were obtained from a depth of 3 feet. Clays sampled from a given place were mixed mechanically. The samples were labeled UC1, UC2 and UC3.

\section{Chemical analysis of clays}

\section{$X$-ray Fluorescence Analysis}

X-ray Fluorescence Spectroscopy, (XRFS) method was used for the chemical analysis in the usual manner using a sequential X-ray spectrophotometer model number PW4025. The results were presented as percentage oxide. 


\section{Flame Photometry and Atomic Absorption Spectroscopy (AAS)}

Analysis of the oxides of $\mathrm{Na}$ and $\mathrm{K}$ were done using a flame photometer model number 410 series . The amount of $\mathrm{CaO}, \mathrm{MgO}, \mathrm{Fe}_{2} \mathrm{O}_{3}$, and $\mathrm{SiO}_{2}$ were determined using AAS model number 6200 - SHIMADZY series. The absorption measurement signal was recorded sequentially each time a new standard solution was used. Calibration curve of concentration of standard solutions versus signal was done. Similar volumes of digested clay sample which corresponded to those of standard solutions were run the on the flame photometer or Atomic Absorption Spectrometer following the instruction manual using standard calibration method.

\section{Calcination of clay}

The sampled clay was dried to a constant weight at $110{ }^{\circ} \mathrm{C}$ to a constant weight using an Electrical Muffle furnace model number OSK 9540-MK-SP $38351.1 \mathrm{~kg}$ of the dried clay, in $18 \mathrm{~cm}$ by $27 \mathrm{~cm}$ clay trough, was put in the furnace and allowed to heat for two hours at $700{ }^{\circ} \mathrm{C}$. The procedure was repeated at $700{ }^{\circ} \mathrm{C}$ for one hour and at $800{ }^{\circ} \mathrm{C}$ for one hour. The resultant clay was cooled, finely ground using laboratory ball mill to $90 \mu \mathrm{m}$ mesh size and subjected to pozzolanicity test.

\section{Pozzolanicity test}

Pozzolanicity test was carried out following the method prescribed by Luxán et al. (1989). Calcium hydroxide solution was prepared in a 250 -ml conical flask by addition of $200 \mathrm{mg}$ of analytical-grade $\mathrm{Ca}(\mathrm{OH})_{2}$ in a $200 \mathrm{ml}$ of de-ionized water. The conical flask was then placed in a magnetic plate and the temperature of the solution maintained at $40 \pm 1{ }^{\circ} \mathrm{C}$. The solution was continuously stirred using a magnetic stirrer. Electrical conductivity of the solution was continuously monitored by a digital conductivity-meter (Oakton CON 510 Series model). After the lime-water system reached a constant conductivity, $5 \mathrm{~g}$ of pozzolanic material was added to the solution in the conical flask. Conductivity values of the solution were recorded at thirty minutes intervals after adding the calcined clays for 270 minutes.

The same procedure was repeated for the pozzolana-water systems without lime. Corrected conductivity-time values for lime - pozzolana system were obtained by subtracting the contribution of pozzolana - water from lime - pozzolana system.

\section{Preparation of PCC}

Requisite amounts of calcined clay and OPC were mechanically mixed using trowels on a tray to make PCC's at $25,30,35,40,45$ and 50 per cent substitution of OPC. They were labeled PCC25, PCC30, PCC35, PCC40, PCC45 and PCC50 respectively.

\section{Sand}

The sampled sand was washed with de-ionized water and sun-dried for two days to a constant weight to remove mud and other soluble substances. The dry sand was sieved to remove coarse material through a $5 \mathrm{~mm}$ sieve.

\section{Compressive Strength Determination}

This was done in accordance with EAS 148-1(2000). Three mortar prisms each having dimensions of $160 \mathrm{~mm} \times 40 \mathrm{~mm} \times 40 \mathrm{~mm}$ were prepared at a go. This was done by mixing $450 \mathrm{~g}$ of OPC and $1350 \mathrm{~g}$ of sand with two trowels on a non - porous plate for one minute. Requisite amount of water was added to make cement mortars with water /cement ratios of $0.4,0.55$ and 0.63 . They were then placed in a curing room with relative humidity above 90 percent and at a temperature of $27 \pm 2{ }^{\circ} \mathrm{C}$ for 24 hours \pm 30 minutes. After 24 hours \pm 30 minutes, they were de - moulded and marked accordingly for identity purpose. The marked prisms were submerged immediately in curing tank maintained at $23{ }^{\circ} \mathrm{C}$ for twenty seven days. On the twenty eighth day, three prisms for each cement category were removed from curing tank and allowed to drain for thirty minutes. The prisms were tested for compressive strength using a Compressive strength machine model number SSC546.

\section{Chloride profiling}

For each category of cement, three prisms, cured for twenty eight days were subjected to chloride profiling using a method prescribed by ASTM C1202-97 (2001). Cathode compartment of an electrochemical set up was filled with $500 \mathrm{~cm}^{3}$ of the 3.5 percent sodium chloride solution. The anode compartment cell was filled with 500 $\mathrm{cm}^{3}$ of the $\mathrm{NaOH}$ solution.

A mortar prism was firmly placed in the assembled test cell using epoxy coating. A stainless steel rod was dipped in each cell such that they were in contact with the periphery faces of the specimen. The rods were 
fastened with a clamp at both ends to hold the whole assembly together. An external voltage cell was used to apply a voltage difference of $12 \pm 0.1 \mathrm{~V}$ between the electrodes.

After the whole assembly was completed and the solutions in both the anode and cathode compartments were in place, the power was switched on. The electric current in the test cell was monitored by use of a digital ammeter at intervals of thirty minutes for a period of thirty six hours. The top of the container was covered with a polyethylene paper and the entire model maintained at $22 \pm 1{ }^{\circ} \mathrm{C}$. Both solutions in the anode and cathode compartments were stirred periodically by use of a glass rod to maintain a relatively uniform concentration throughout the compartment depth.

After exposure duration, the mortar prisms were removed from the electrochemical set up. The mortar prisms were packed and sealed in plastic bags. A mortar prism, from the plastic bag, was polished from all sides using sand paper. The prism was cut into $10 \mathrm{~mm}$ slices along the length using $2 \mathrm{~mm}$ thick water lubricated saw. The slices were dried to a constant mass in an oven at $105^{\circ} \mathrm{C}$.

The dried slices were pulverized and ground to pass through $76 \mu \mathrm{m}$ sieve. Between each grinding or pulverization, the grinder or pulverizer was thoroughly cleaned to avoid cross sample contamination. The ground samples were kept in a sealed plastic bags awaiting chloride analysis.

Chemical Analysis Results for Sampled Clays

\section{Results and discussion}

Table 3.1- 3.3 shows the chemical composition in terms of oxides of sampled clays from selected regions within Ugweri region.

Table 3.1: Chemical Composition of the Sampled Clays (XRF Analysis)

\begin{tabular}{|c|c|c|c|c|c|c|}
\hline Oxide $\%$ & $\mathrm{UC} 1$ & \pm S.D & $\mathrm{UC} 2$ & \pm S.D & UC3 & \pm S.D \\
\hline $\mathrm{Al}_{2} \mathrm{O}_{3}$ & 20.70 & \pm 0.02 & 16.0 & \pm 0.01 & 22.17 & \pm 0.02 \\
\hline $\mathrm{SiO}_{2}$ & 43.40 & \pm 0.36 & 72.6 & \pm 0.00 & 33.44 & \pm 0.05 \\
\hline $\mathrm{Fe}_{2} \mathrm{O}_{3}$ & 2.30 & \pm 0.57 & 2.72 & \pm 0.01 & 2.30 & \pm 0.60 \\
\hline $\mathrm{Al}_{2} \mathrm{O}_{3}+\mathrm{SiO}_{2}+\mathrm{Fe}_{2} \mathrm{O}_{3}$ & 66.4 & \pm 0.89 & 91.32 & \pm 0.02 & 57.91 & \pm 0.59 \\
\hline
\end{tabular}

Table 3.2: Chemical Composition of the Sampled Clays (AAS Analysis)

\begin{tabular}{|c|c|c|c|c|c|c|}
\hline Oxide $\%$ & $\mathrm{UC1}$ & \pm S.D & UC2 & \pm S.D & UC3 & \pm S.D \\
\hline $\mathrm{Al}_{2} \mathrm{O}_{3}$ & 22.01 & \pm 0.06 & 16.4 & \pm 0.65 & 23.57 & \pm 0.20 \\
\hline $\mathrm{Fe}_{2} \mathrm{O}_{3}$ & 1.90 & \pm 0.04 & 2.61 & \pm 0.02 & 2.52 & \pm 0.17 \\
\hline $\mathrm{MgO}$ & 0.40 & \pm 0.01 & 0.2 & \pm 0.02 & 0.27 & \pm 0.14 \\
\hline
\end{tabular}

Table 3.3: Chemical Composition of $\mathrm{Na}_{2} \mathrm{O}$ and $\mathrm{K}_{2} \mathrm{O}$ in the Sampled Clays (Flame photometry Analysis) KS 02 1260(1994) and ASTM C618 (2003) prescribes that the sum of $\mathrm{Al}_{2} \mathrm{O}_{3}, \mathrm{SiO}_{2}$ and $\mathrm{Fe}_{2} \mathrm{O}_{3}$ should be above

\begin{tabular}{|c|c|c|c|c|c|c|}
\hline Oxide $\%$ & UC1 & \pm S.D & $\mathrm{UC} 2$ & \pm S.D & UC3 & \pm S.D \\
\hline $\mathrm{Na}_{2} \mathrm{O}$ & 0.05 & \pm 0.01 & 0.13 & \pm 0.02 & 0.42 & \pm 0.02 \\
\hline $\mathrm{K}_{2} \mathrm{O}$ & 0.78 & \pm 0.02 & 0.72 & \pm 0.07 & 0.69 & \pm 0.04 \\
\hline
\end{tabular}

70 percent. The sum of these oxides of UC2 surpassed the aforementioned specifications. The oxides are essential in any pozzolana as they provide the siliceous and aluminous material that reacts with lime during the hydration reactions of blended cements.

IV. Pozzolanicity Test Results

Selected Pozzolanicity test results are presented in figure 3.1. They are presented as percentage loss of conductivity against time. 


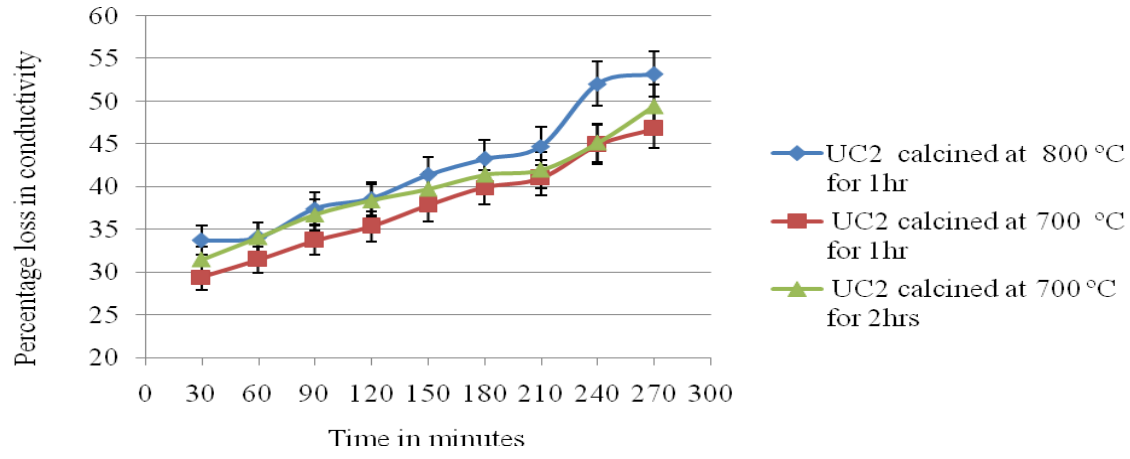

Figure 3.1: Pozzolanicity as a Function of Loss of Conductivity with Time for UC2 Clay Calcined at Different Temperatures and/or Time

It was observed that the calcined clays resulted in decreased conductivity of the water - lime mixture. The loss in electrical conductivity is due to lime fixation as a result of pozzolanic reactivity (Taylor, 1997). The three sample clays, UC1, UC2 and UC3, exhibited pozzolanic properties when calcined at different temperatures. Incinerating the clay samples at temperature of $800{ }^{\circ} \mathrm{C}$ for one hour was observed to be the optimum calcining temperature for all the clay samples. Heating clays at elevated temperatures is necessary to produce a reactive pozzolana (Gathua, 2005). Among the three clay samples, UC2 was observed to exhibit the highest pozzolanic activity. This could be attributed to its higher $\mathrm{Al}_{2} \mathrm{O}_{3}, \mathrm{SiO}_{2}$ and $\mathrm{Fe}_{2} \mathrm{O}_{3}$ content than the others. UC2 calcined at $800{ }^{\circ} \mathrm{C}$ for one hour was therefore subjected to further analysis.

\section{Compressive Strength Test Results}

4.4.1 Compressive Strength Test Results after 28 Days Curing

The compressive test results are given in figure 4.4

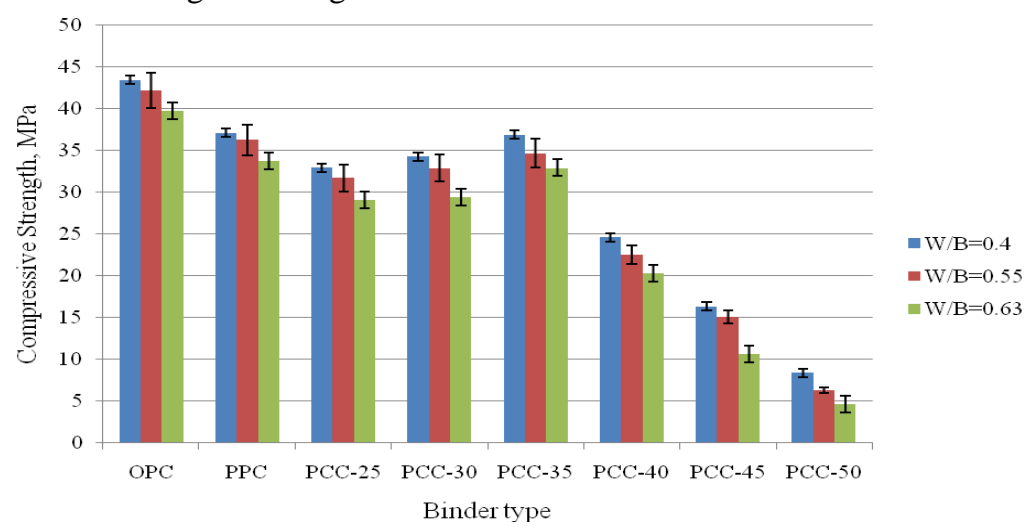

Figure 4.4: Compressive Strength of Test Cements on Verses Binder Type the Twenty Eighth of Curing It was observed that $\mathrm{w} / \mathrm{b}$ ratio greatly influenced the strength of all test cements mortars at the twenty eighth day. The strength decreased in the order $w / b=0.4>\mathrm{w} / \mathrm{b}=0.55>\mathrm{w} / \mathrm{b}=0.63$. This is because $\mathrm{w} / \mathrm{b}$ ratio affects the porosity of the hardened paste and the flow or rheology of the mixture as well as cohesion between paste and aggregate (Bentz, 2006).

OPC showed the highest compressive strength as compared to all test cements irrespective of the w/b ratio used. This could be attributed to the fact that OPC contained a higher proportion of $\mathrm{C}_{3} \mathrm{~S}$ and $\mathrm{C}_{2} \mathrm{~S}$ that are mainly responsible for the strength development (Rahhal and Talero, 2005). There was notable variation in strength at various replacement levels of OPC with calcined clays. At each w/b ratio, there was increase in compressive strength from PCC25 to PCC 35. When calcined clay is used as part of the cementitious material in a mortar/concrete mix, it reacts with water and $\mathrm{Ca}(\mathrm{OH})_{2}$ to form more CSH. The additional CSH densifies the mortar/concrete matrix enhancing strength (Muller, 2005). The increase in the amount of calcined clays used avails the needed alumino-silicate material to react with the calcium hydroxide produced during the hydration of OPC (Muller, 2005).

There was markedly a progressive decline in compressive strength at increasing replacement levels from 35 percent to 50 percent. Similar observations were made by Darweesh et al. (2007) while working with calcined bentonite clays. The worker attributed this to presence of residual inactive or unreacted bentonite minerals as result of low amount of CH. Moreover, the researchers (Darweesh et al., 2007) attributed this to the fact that the high replacement levels of OPC with calcined bentolite clays resulted to a decrease in the primary 
binding materials originating from hydration of OPC. More so, the authors attributed this to the fact that although calcined bentonite clays provided the aluminosilicate material for the pozzolanic reaction, the $\mathrm{CH}$ produced by hydration of OPC at these replacement levels, was increasingly becoming insufficient for pozzolanic reaction.

The minimum standard requirements of compressive strength for cement mortar prisms by EAS 1481(2000), specifies a 28 days compressive strength of $32.5 \mathrm{MPa}$ for Portland pozzolana cements. PCC cement met this specification up to 35 per cent replacement of OPC by mass regardless of the w/b used. Compressive strength values for PCC40 - PCC50 did not meet this standard. There was no significant difference in terms of compressive strength gain between PCC35 and commercial PPC at w/b $=0.40, \mathrm{w} / \mathrm{b}=0.55, \mathrm{w} / \mathrm{b}=0.63$ as the Tcalculated values were $0.594,0.354$ and 0.499 respectively. The T- calculated values were far below the Tcritical value of 6.314. Similarly, there was no significant difference in terms of compressive strength between PCC30 and commercial PPC at $\mathrm{w} / \mathrm{b}=0.40, \mathrm{w} / \mathrm{b}=0.55, \mathrm{w} / \mathrm{b}=0.63$ as the $\mathrm{T}$ - calculated values were $0.303,0.270$ and 0.008 respectively. The T- calculated values were also way below the T- critical value of 6.314 .

\subsubsection{Compressive Strength Results after Exposure to Chloride Ions Solution}

The percent gain in compressive strength results after exposure of the mortar in 3.5 percent sodium chloride solution are given in Figure 4.5

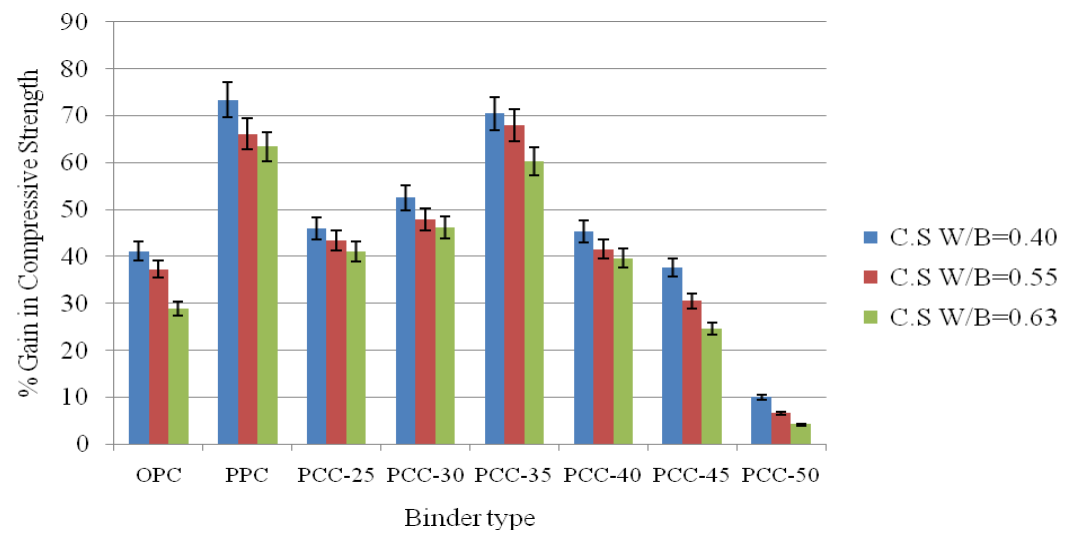

Figure 4.5: Percentage Gain in Compressive Strength verses Binder Types at varying w/b ratios

It was observed that in all cement categories, there was an increase in compressive strength after exposure to the $\mathrm{Cl}^{-}$media. The gain could be attributed to the ingress of sodium and chloride ions in the cement matrix (Luke, 2006). The $\mathrm{Na}^{+}$and $\mathrm{Cl}^{-}$are known to activate or initiate residual cement hydration or pozzolanic reaction and thus increase strength of mortar /concrete (Lorenzo et al., 2003). Lorenzo et al. (2003) observed an increase in flexural strength of samples that contained fly ash in marine simulated media. The researchers attributed this to the ingress of $\mathrm{Na}^{+}$and $\mathrm{Cl}^{-}$.

There was marked decrease in compressive strength gain from PCC40 - PCC50. Similar observations were made by Muller (2005) while studying the pozzolanic activity of natural clay minerals with respect to environmental geotechnics. The author observed that at replacement levels above 35 percent of OPC by mass caused a decrease in strength irrespective of the presence of chemical activators. The worker (Muller, 2005) attributed this to low pozzolana $-\mathrm{CH}$ reaction. Our results can also be explained in a similar way.

There was notable increase in compressive strength in all categories of cements at various w/b ratios. There was no significance difference in terms of compressive strength gain between PCC35 and commercial $\mathrm{PPC}$ at $\mathrm{w} / \mathrm{b}=0.40, \mathrm{w} / \mathrm{b}=0.55, \mathrm{w} / \mathrm{b}=0.63$ as the $\mathrm{T}$ - calculated values were $0.1621,0.5321$ and 0.2871 respectively. The T- calculated values were far below the T- critical value of 6.314. Similarly, there was no significance difference in terms of compressive strength gain between PCC30 and commercial PPC at w/b = $0.40, \mathrm{w} / \mathrm{b}=0.55, \mathrm{w} / \mathrm{b}=0.63$ as the $\mathrm{T}$ - calculated values were $0.1697,0.1329$ and 0.1201 respectively. The Tcalculated values were also way below the T- critical value of 6.314 .

\subsection{Ingressed Chloride Profiling}

Selected Chloride profiles for the chloride penetration against depth of cover for each category of the cement mortar are presented in Figures 4.6. Chloride profile analysis in this study involved the determination of the concentration of the ions $\left(\mathrm{Cl}^{-}\right)$at different depths of cement mortar bulk of PCC, OPC and PPC. 


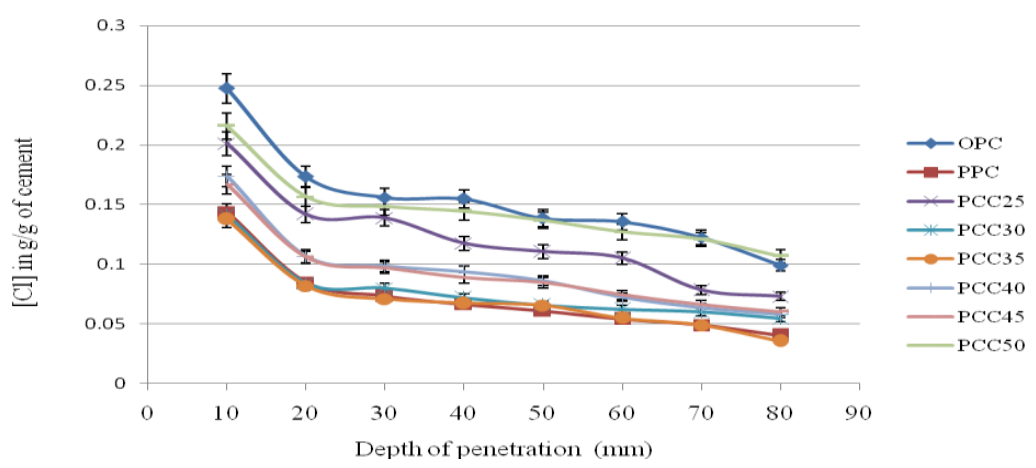

Figure 4.6: Graph of Concentration of Chloride Ions in $\mathrm{g} / \mathrm{g}$ of Cement Mortar Verses Depth (mm) at $0.4 \mathrm{w} / \mathrm{b}$ It was observed that in all categories of cements, the total chloride decreased with increase in depth of penetration. This was even more pronounced as the w/c ratio reduced. There is sharp decrease in the amount of chlorides at the shallow depths of cover $(<20 \mathrm{~mm})$. This could be attributed to chloride binding capacity and diffusivity of chlorides in the cement mortar ( Qiang, 2009). All cements bind a proportion of the chloride present (Hirao et al., 2005). Chloride binding reduces diffusion rates of chlorides into the cement bulk of the cement involved (Hirao et al., 2005).

At greater depths of cover $(>20 \mathrm{~mm})$, it was observed that the OPC exhibited the highest chloride ingress especially at higher w/c ratios. This can be attributed to the fact that blended cements have lower $\mathrm{CH}$ than OPC in their pore solution (Bao-min and Li-Jiu, 2004; Hirao et al., 2005). A low amount of CH in blended cements is as a result of pozzolanic reaction (GjØrv and Vennesland, 1979). $\mathrm{CH}$, acts as the main source of $\mathrm{OH}^{-}$ hence the decreased amount of $\mathrm{OH}^{-}$leads to a lower exchange capacity between the $\mathrm{OH}^{-}$and the chlorides in the pore water (GjØrv and Vennesland, 1979). These factors clearly explain the low chloride ingress in blended cements used in this study.

Blended cements exhibited lower chloride ingress compared to OPC. The use of pozzolana has been reported to lower the chloride ingress in mortar /concrete (Gonçalves, 2009). The resistance to aggressive attack of PPC's has been attributed to factors such as the pore refinement of its microstructure, the low alkalinity of its pore solution, and the low portlandite, $\mathrm{Ca}(\mathrm{OH})_{2}$, content. These factors, which arise from the pozzolanic reaction, impede diffusion of aggressive ions such as chlorides (Lorenzo et al., 2002).

The presence of pozzolana leads to a greater precipitation of cement gel products than occurs in OPC, which more effectively block the pores more effectively and therefore helping to reduce permeability (Garci'a $e t$ al., 2000). The water-soluble calcium hydroxide liberated by hydrating cement may leach out of hardened concrete and leave voids for the ingress of water. In the pozzolanic reaction, by combining with the Calcium hydroxide $(\mathrm{CH})$ directly reduces the amount of $\mathrm{CH}$, which can reduce the leaching of $\mathrm{CH}$ (Garc1'a et al., 2000). The additional products from pozzolanic reaction, C-S-H will close the voids, which result in more dense concrete, and consequently reduce the permeability of concrete arising from a pore refining process ( Bai et al., 2003).

Beyond 35 percent replacement of OPC, the amount of chloride ingress in cement mortar gradually increased at all w/b. This is perhaps due to the fact that replacement of OPC beyond 35 percent, the added pozzolana only serves as a filler material with low resultant CSH. Similar observations were made by Khater $e t$ al. (2010) although studying the Influence of metakaolin on resistivity of cement mortar to magnesium chloride solution. The researchers attributed this to low chloride binding with increase in amount of pozzolana added due to formation of highly porous and less dense cement mortar with low amount of CSH.

As the $\mathrm{w} / \mathrm{b}$ ratio increased, there was a marked rise in the chloride ingress in all the profile depths of the test cements in the order $0.4<0.55<0.63$. A high w/c ratio is known to contribute to a higher permeability consequently increasing the ingress of chlorides in cement pastes (Page et al., 1986). When the w/b ratio increases, the porosity of the resultant mortar increases (Wild et al., 1996). This results in higher diffusivity of the chloride into the mortar. Vaishali et al. (2011) although, studying the chloride ion permeability studies of metakaolin based high performance concrete observed that cement mortar with w/b ratios of 0.3 had a lower chloride content than those cast at a w/b ratio of 0.5 . The workers attributed this to the fact that decreased $\mathrm{w} / \mathrm{b}$ ratio increases the resistance of concrete/mortar by lowering permeability and porosity.

There was no significance difference in terms of chloride ingress between PCC35 and commercial PPC at w/b = $0.40, \mathrm{w} / \mathrm{b}=0.55, \mathrm{w} / \mathrm{b}=0.63$ as the $\mathrm{T}$ - calculated values were $0.1621,0.5321$ and 0.2871 respectively. The Tcalculated values were far below the T- critical value of 6.314. Similarly, there was no significance difference in terms of compressive strength gain between PCC30 and commercial PPC at w/b $=0.40, \mathrm{w} / \mathrm{b}=0.55, \mathrm{w} / \mathrm{b}=$ 0.63 as the T- calculated values were $0.1697,0.1329$ and 0.1201 respectively. The T-calculated values were also way below the T- critical value of 6.314 . 


\subsection{Apparent Chloride Diffusion Coefficients}

The error fitting curve for determination of apparent chloride diffusion coefficient $\left(\mathrm{D}_{\text {app }}\right)$ for the test cement, PCC50 mortar at $\mathrm{w} / \mathrm{b}=0.63$ is presented in figure 4.9. Moreover, the error fitting data for each cement category is presented in table $4.5-4.7$. Similar error fitting curves were used for determination of the apparent diffusion coefficients for each cement category at $w / b=0.40, w / b=0.55$ and $w / b=0.63$.

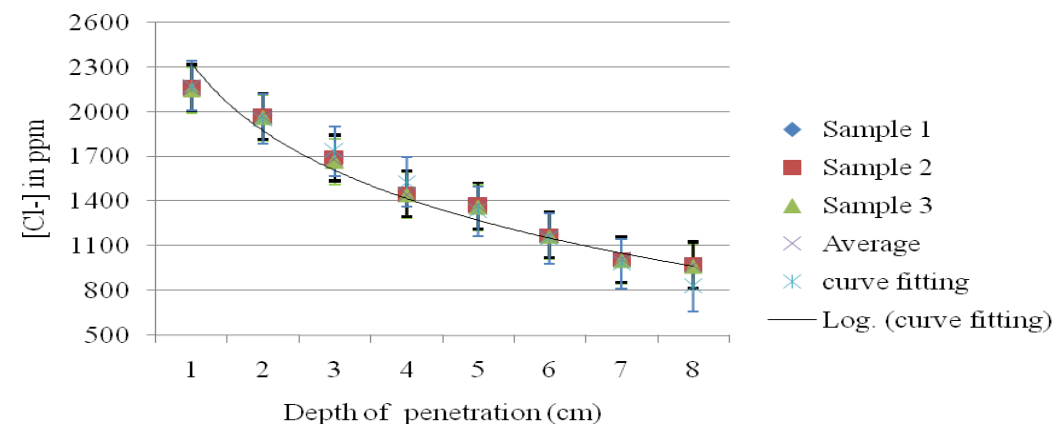

Figure 4.9: Error Function Fitting Curve for PCC50 (w/b $\left.=0.63, D_{\text {app }}=1.832 \times 10^{-11} \mathrm{~m}^{2} / \mathrm{s}, \mathrm{r}^{2}=0.954\right)$

Table 4.4: $D_{\text {mig, }} D_{\text {app }}$ and $r^{2}-$ Values for different Cement Mortars at $w / b=0.40$

\begin{tabular}{lccc}
\hline Binder type & \multicolumn{2}{c}{$\mathrm{W} / \mathrm{B}=0.40$} & \\
\cline { 2 - 4 } & $\mathrm{D}_{\text {mig }}\left(\mathrm{m}^{2} / \mathrm{s}\right) \times 10^{-10}$ & $\mathrm{D}_{\text {app }}\left(\mathrm{m}^{2} / \mathrm{s}\right) \times 10^{-12}$ & \\
\hline PCC25 & 1.559 & 8.777 & 0.961 \\
PCC30 & 1.332 & 7.499 & 0.966 \\
PCC35 & 1.234 & 6.948 & 0.969 \\
PCC40 & 1.552 & 8.738 & 0.961 \\
PCC45 & 1.562 & 8.795 & 0.961 \\
PCC50 & 1.890 & 10.64 & 0.955 \\
PPC & 1.234 & 6.948 & 0.969 \\
OPC & 2.773 & 15.61 & 0.945 \\
\hline
\end{tabular}

Table 4.5: $\mathrm{D}_{\text {mig }}, \mathrm{D}_{\text {app }}$ and $\mathrm{r}^{2}$ - Values for different Cement Mortars at $\mathrm{w} / \mathrm{b}=0.55$

\begin{tabular}{lccc}
\hline Binder type & & $\mathrm{W} / \mathrm{B}=0.55$ & $\mathrm{r}^{2}$ \\
\cline { 2 - 4 } & $\mathrm{D}_{\text {mig }} \times 10^{-10} \times 10^{-12}$ & 0.947 \\
PCC25 & 2.609 & 14.688 & 0.962 \\
PCC30 & 1.528 & 8.602 & 0.964 \\
PCC35 & 1.424 & 8.015 & 0.961 \\
PCC40 & 1.597 & 8.993 & 0.960 \\
PCC45 & 1.632 & 9.192 & 0.955 \\
PCC50 & 1.929 & 10.860 & 0.969 \\
PPC & 1.231 & 6.933 & 0.942 \\
OPC & 3.210 & 18.069 & \\
\hline
\end{tabular}

Table 4.6: $D_{\text {mig, }} D_{\text {app }}$ and $r^{2}-$ Values for different Cement Mortars at $w / b=0.63$

\begin{tabular}{lccc}
\hline Binder type & \multicolumn{3}{c}{$\mathrm{W} / \mathrm{B}=0.63$} \\
\cline { 2 - 4 } & $\mathrm{D}_{\text {mig }}\left(\mathrm{m}^{2} / \mathrm{s}\right) \times 10^{-10}$ & $\mathrm{D}_{\mathrm{app}}\left(\mathrm{m}^{2} / \mathrm{s}\right) \times 10^{-11}$ & $\mathrm{r}^{2}-$ values \\
\hline PCC25 & 2.820 & 1.587 & 0.945 \\
PCC30 & 1.964 & 1.106 & 0.954 \\
PCC35 & 1.453 & 0.818 & 0.964 \\
PCC40 & 1.968 & 1.108 & 0.954 \\
PCC45 & 1.968 & 1.109 & 0.954 \\
PCC50 & 3.255 & 1.832 & 0.954 \\
PPC & 1.259 & 0.708 & 0.968 \\
OPC & 3.382 & 1.904 & 0.941 \\
\hline
\end{tabular}

It was observed that the higher the $w / b$ the higher was the $D_{\text {app }}$ across all cement categories. Similar observations were made by Paya et al. (2010) and Vaishali et al.(2011). The workers attributed this to the fact that high $\mathrm{w} / \mathrm{b}$ affects porosity mortars. The connectivity of the pore system depends on the amount of original mixing-water filled space and the degree to which it has been filled with hydration products ( Wallah et al., 2004). This could explain why increase in $\mathrm{w} / \mathrm{b}$ ratios resulted to increased diffusion coefficients. 
It was observed that the blended cements showed lower $\mathrm{D}_{\text {app }}$ than OPC at all w/b ratios. Anwar et al. (2001) although investigating the influence of RHA in concrete observed a lower ratio of soluble/total chloride ions content than those of OPC concretes. The worker (Anwar et al., 2001) attributed this to the fact that chloride penetration into concrete is affected by the chloride binding capacity of the concrete. Blended cements have been found to bind more chlorides than OPC (Schlangen at al., 2007). High chloride binding ability effectively removes a large proportion of chloride ions in the pore structure of a cement mortar (Schlangen at al., 2007). This leads to low chloride ingress in the cement mortar characterized by low $\mathrm{D}_{\text {app }}$ as observed in this study. The chloride binding capacity is controlled by the amount of cementing materials used and the $\mathrm{C}_{3} \mathrm{~A}$ content in the concrete (Hossain, 2005). $\mathrm{C}_{3} \mathrm{~A}$ content of the cement influences its binding capacity, with increased $\mathrm{C}_{3} \mathrm{~A}$ content leading to increased binding (Hossain, 2005).

In this study, there was a marked decrease in $\mathrm{D}_{\text {app }}$ from PCC25 to PCC 35. Similar observations were made by Khan (2010) although investigating the chloride ingress resistance of high performance concrete containing supplementary composites silica fumes, by up to 10 percent replacement level of OPC. The researcher, observed a significant decrease in the chloride diffusion coefficients in binary systems with increase in amount of silica fume. The researcher attributed this to the increased chloride binding with increase in the amount of pozzolana added (silica fume). Vaishali et al. (2011), although working on chloride ion permeability studies of metakaolin based high performance concrete, observed that the chloride diffusion coefficients decreased with increase in OPC replacement levels up to 30 percent. The author attributed this to densification of concrete by addition of pozzolana thus lowering porosity. Increased chloride binding and low porosity are therefore the major factors that lead to the decrease in $\mathrm{D}_{\text {app }}$ from PCC25 to PCC 35.

There was a notable increase in apparent diffusion coefficients from PCC40 - PCC50 at all the w/b ratios considered. This is due to low amount of secondary cementious materials formed as a result of minimal pozzolanic reaction. There was marked decrease in compressive strength development in the said cements as shown in Figure 4.4 and 4.5.

OPC exhibited the highest $\mathrm{D}_{\text {app }}$ values regardless of the $\mathrm{w} / \mathrm{b}$ ratio used. This can be attributed to high exchange capacity of $\mathrm{OH}^{-}$(Qiang, 2009; Poon et al., 2006), low $\mathrm{Al}_{2} \mathrm{O}_{3}$ phase due to lack of pozzolana inclusion (Balonis and Glasser, 2009). Similar observations were made by Lothenbach and Winnefeld (2006) while studying thermodynamic modeling of the hydration of Portland cement.

There was no significant difference in chloride ingress between PCC 35 and commercial PPC at $w / b=0.40, w / b$ $=0.55, \mathrm{w} / \mathrm{b}=0.63$ as the T- calculated values were $0.1621,0.5321$ and 0.2871 respectively. The $\mathrm{T}$ - calculated values were far below the T- critical value of 6.314. Similarly, there was no significant difference in terms of compressive strength gain between PCC30 and commercial PPC at w/b $=0.40, \mathrm{w} / \mathrm{b}=0.55, \mathrm{w} / \mathrm{b}=0.63$ as the Tcalculated values were $0.1697,0.1329$ and 0.1201 respectively. The T- calculated values were also way below the T- critical value of 6.314. From the chloride profiles in figures $4.6-4.8$, the test cements exhibited similar ingress in chloride ions across all depths of cover. Similarly, from the compressive strength development (figure 4.4), there was no statistical difference between the test cements. Clearly, this shows the test cements PCC30, and PCC35 can be used in similar environments as commercial PPC. This can be attributed to packing of pozzolana grain in hydrated cement (Arya et al., 1990; Guerrero et al., 2000), formation of secondary cementious materials thereby decreasing permeability ( Bai et al., 2003; Luke, 2006) as well as inclusion of the $\mathrm{Cl}^{-}$binding $\mathrm{Al}_{2} \mathrm{O}_{3}$, from pozzolana (Lorenzo et al., 2003; Barberon et al., 2005).

\section{Acknowledgements}

The authors would like to express their appreciation to the laboratory staff at the civil engineering department in Jomo Kenyatta University of Agriculture and technology. We are also indebted to the laboratory technicians at Kenyatta University and Geology and mines department located in industrial Area in NairobiKenya for their immense contribution to our research.

\section{References}

[1]. Anwar, M.; Miyagawa, T. and Gaweesh, M. (2001). Using Rice Husk Ash as a Cement Replacement Material in Concrete. In the Proceedings of the 2001 first international Ecological Building Structure Conference, pp. 671- 684.

[2]. Arjunan, P.; Silsbee, M.R. and Roy, D.M. (2005). Chemical Activation of Low Calcium Fly Ash. Part I : Identification of Suitable Activators and their Dosage. Proceedings Of The International Ash Utilization Symposium, Center for Applied Energy Research, University Of Kentucky, pp. 22-24.

[3]. Arya, C.; Buenfeld, N.R. and Newman, J.B. (1990). "Factors Influencing Chloride-binding in Concrete", Cement and Concrete Research, 20, pp. 291-300.

[4]. ASTM C1202-97 (2001). Standard Test Method for Electrical Indication of Concrete's Ability to Resist Chloride Ion Penetration. Annual Book of ASTM standards, 04, pp. 646-51. 
[5]. ASTM C618 (2003). Standard Specification for Coal Fly Ash and Raw or Calcined Natural Pozzolans for Use in Concrete. In: Annual Book of ASTM Standards.ASTM International, West Conshohocken,PA, USA, pp. 323-325.

[6]. Bai, J.; Wild, S. and Sabir, B.B. (2003). Chloride Ingress and Strength Loss in Concrete With PC-PFA-MK Binder Compositions Exposed to Synthetic Seawater, Cement and Concrete Research, 33, pp.353 - 362.

[7]. Balonis, M. and Glasser, F.P. (2009). The Density of Cement Phases. Cement and Concrete Research, 39, pp. 733-739.

[8]. Bao-min, W. and Li-jiu, W. (2004). Development of Studies and Applications of Activation of Fly Ash. Proceedings of the International Workshop on Sustainable Development and Concrete Technology, Beijing, China, pp. 159-169.

[9]. Bentz, D. P. (2006). 'Influence of Water-to-Cement Ratio on Hydration Kinetics: Simple Models Based on Spatial Considerations'. Cement Concrete Research, 36, pp. 238-244.

[10]. Bertolini, L., Elsner, B., Pedeferri, P. and Polder, R. (2004) Corrosion of Steel in Concrete: Prevention, Diagnosis, Repair. WileyVCH Verlag GMbH \& Co. KGaA, Weinheim.

[11]. Darweesh, H.H. and Nagieb Z. A.,(2007). Hydration of Calcined Bentonite Portland Blended Cement Pastes. Indian Journal of Chemical Technology, 14, pp. 301-307.

[12]. Garci'a, C.; Climent, M.A.; De Vera, J. Lo'pez, C. and Andrade. G. (2000). Transport of Chlorides through Non-Saturated Concrete after an Initial Limited Chloride Supply, 2nd International RILEM Workshop On "Testing and Modelling the Chloride Ingress Into Concrete,', Paris, pp. 33.

[13]. Gathua, J.K. (2005). Pozzolanicity of Selected Kaolinites with Special Focus on Pyroprocessing Parameters, PhD Thesis. Department of Physics. Kenyatta University, Nairobi, pp. 75 - 121.

[14]. Ghebreyesus, T.A.; Haile, M.; Written, A.; Yetachew, A.; Yahannes, M.; Lindsay,S. W. and Byass, (2000). Household Risk Factors for Malaria among Children in the Ethiopian Highlands, Transition of the Royal Society of Tropical Medicine and Hygine, 94, pp. $17-21$.

[15]. Gjorv. O. E. and O. Vennesland, (1979). "Diffusion of Chloride Ions from Seawater Concrete", Cement and Concrete Research, 9, pp. 229-238.

[16]. Gonçalves J. P.(2009). Performance evaluation of cement mortars modified with metakaolin or ground brick, Construction and Building Materials, 23, pp. 1971-1979.

[17]. Guerrero, A.; Hernández, M.S. and Goñi, S. (2000). Effect of Simulated Radioactive Liquid Waste on the Microstructure of Cementious Materials: Portlandite Orientation and Saturation Factors in the Pore Solution, Journal of American Ceramic Society, 83, pp. 2803 - 2808.

[18]. Grove, T.; Chatterjee, N; Parman, S. and Medard, E. (2006). "The Influence of $\mathrm{H}_{2} \mathrm{O}$ on Mantle Wedge Melting". Earth and Planetary Science Letters 249 pp. 74-89.

[19]. Hirao, H; Yamada, K.; Takahashi, H. and Zibara H.(2005). Chloride binding of cement estimated by binding isotherms of hydrates, Journal of Advanced Concrete Technology, 3, pp. 77-84.

[20]. Hossain K.M.A. (2005). Chloride Induced Corrosion of Reinforcement in Volcanic Ash and Pumice Based Blended Concrete, Cement and Concrete Research Composites, 27 (3), pp. 381-390.

[21]. Jones, M.R. and Dhir R.K., (2000). A Review on Concrete Economic and Durable Concrete through Excellence, E \& FN Spon, London, pp. 1799-1811.

[22]. KEBS(1994). Kenya Standard Specification for Portland Pozzolana Cements, KS1775 part 5. Kenya Bureau of Standards.

[23]. Khan, A. R..; Al-Gadhib, A. H. and Baluch, M. H.(2010). "Experimental and Computational Modeling of Low Cycle Fatigue Damage of CFRP Strengthened Reinforced Concrete Beams," Int. J. Damage Mech., pp. 237.

[24]. Khater, M. and Hisham,J. (2010). Influence of Metakaolin on Resistivity of Cement Mortar to Magnesium Chloride Solution. Housing and Building National Research Centre (HBNRC) 87 El-Tahreer St., Dokki, Giza, P.O. Box 1770 Cairo, Egypt. pp. 326.

[25]. Laban, U.;Benedetti, W. (2002). Burnt Clay Waste as a Pozzolanaic Material In Kenya. Journal of Civil Engineering JKUAT, 7, pp. 21-28.

[26]. Lorenzo, M.; Goni, S and Guerrero, A. (2003). Activation of Pozzolanic Reaction of Hydrated Portland Cement Fly Ash Pastes in Sulfate Solution, Institute of Construction Science Eduardo Torroja, pp. 123.

[27]. Luke, K. (2006)."Microstructure of Early Age Hydration of Natural Zeolite with Pure Cement Pastes," Proceedings of the 28th Conference on Cement Microscopy, Denver, Colorado, pp 10-21.

[28]. Luxán, M.P.; Madruga, F.; Saavedra, J. (1989). Rapid Evaluation of Pozzolanic Activity of Natural Products by Conductivity Measurement, Cement and Concrete Research, (19), pp. 63-68.

[29]. Muller, C.J. (2005). Pozzolanic Activity of Natural Clay Minerals With Respect to Environmental Geotechnics. Dissertation, Swiss Federal Institute of Technology Zurich, Switzerland, pp. 342.

[30]. Muthengia, J.W. (2008). Effects of Selected Aggressive Ions on Pozzolana Based Cement made from Industrial and Agricultural Wastes, Ph.D Thesis. Department of Chemistry. Kenyatta University, Nairobi, pp. 4-19

[31]. Neville, A. M. (1995). Properties of concrete. Prentice Hall, London, pp. 1-14.

[32]. Page, C.L.; Short, N.R. and Holden, W.R. (1986). The Influence of Different Cements on Chloride-Induced Corrosion of Reinforcing Steel, Cement and Concrete Research, 16, 79 -86.

[33]. Paya, J.; Borrachero, M.V.; Monzo, J. Peris-Mora, E. and Amahjour, F., (2010). Enhanced conductivity measurement techniques for evaluation of fly ash pozzolanic activity, Cement Concrete Research, (31) pp 41-49.

[34]. Rahhal, V. \& Talero, R. (2005). Early Hydration of Portland Cement with Crystalline Mineral Additions. Cement and Concrete Research, 35, pg 1285-1291.

[35]. Qiang, (2009). "Chloride Binding of Cement-Based Materials Subjected to External Chloride Environment - A Review", Construction and Building Materials, 23, pp. 1-13

[36]. Vaishali, G. G. and Sudarsana, R. (2011). Chloride Permeability Studies of Metakaolin Based High Performance Concrete. JNTUA College of Engineering, pp.1617 - 1623.

[37]. Wallah, S. E.; Hardjito, D.; Sumajouw, D. M. J. and Rangan, B. V., (2004)."Factors Influencing the Compressive Strength of Fly Ash-Based Geopolymer Concrete", Civil Engineering Dimension, 6, pp. 88-93.

[38]. Wild, S.; Khatib, J.M. Jones, A (1996). Relative Strength, Pozzolanic Activity and Cement Hydration in Superplasticized Metakaolin Concrete. Cement Concrete Research. 26, pp 1537-1544 